\title{
Reducing muscle tension and pain in trapezius, after application of ventosatherapy in patients with postural scapular dysfunctions
}

\author{
Diminuição da tensão muscular e dor em trapézio, após a \\ aplicação de ventosaterapia em pacientes com disfunções \\ escapulares posturais
}

\author{
Sheron Stefany Dutra Ritter Michalska ${ }^{1}$ \\ Carla Itatiana Bastos de Brito ${ }^{2}$ \\ Daniel Pfeifer Campani ${ }^{3}$
}

\begin{abstract}
Introduction: Postural changes due to muscle tensions also generate muscle pain and are increasingly common nowadays, affecting mainly the young-adult population. The manual vacuum suction cup is an ancient technique, capable of promoting tension reduction, generating muscle relaxation and consequently relieving pain. Objective: To evaluate the acute and chronic effects of massage therapy with a manual vacuum cup in sliding mode on muscle relaxation in the trapezius muscle by evaluating the position of the scapulae and on pain. Methodology: This is an quasi-experimental quantitative longitudinal clinical study, with a sample of 25 individuals, both sexes, aged between 18 and 35 years, residents of the city of Porto Alegre-RS and metropolitan region and who do not have diseases associates. The method used for data collection consisted of a postural examination and an assessment of pain classification through: a) the application of the Visual Analog Scale (VAS); b) subjective clinical observation; c) the reference measurements of the scapula. Results: There was a significant improvement in pain reduction and scapular postural alignment, both in height and in the tipper. Conclusion: Suction cup therapy proved to be a safe method, easy to apply and with good results in terms of reducing muscle tension, improving postural alignment and reducing pain in the individuals evaluated.
\end{abstract}

\section{KEYWORDS}

Ventosatherapy; Muscle tension; Pain and scapular posture alignment.

\footnotetext{
${ }^{1}$ Physiotherapist formed by Centro Universitário Metodista - IPA - Porto Alegre, RS, Brasil.

${ }^{2}$ Physiotherapist and professor of the Physiotherapy Course at Centro UniversitárioMetodista - IPA - Porto Alegre, RS, Brasil.

${ }^{3}$ Physiotherapist and professor of the Physiotherapy Course at Centro UniversitárioMetodista - IPA - Porto Alegre, RS, Brasil.
} 


\section{RESUMO}

Introdução: As alterações posturais devido a tensões musculares, geram também dores musculares e são cada vez mais comuns na atualidade prejudicando principalmente a população adulto-jovem. A ventosarapia manual a vácuo é uma técnica milenar, capaz de promover redução de tensões, gerando o relaxamento muscular e consequentemente aliviando a dor. Objetivo: Avaliar os efeitos agudos e crônicos da massoterapia com ventosa manual a vácuo em modo deslizante sobre o relaxamento muscular no músculo trapézio através da avaliação da posição das escápulas e sobre a dor. Metodologia: Trata-se de um estudo clínico longitudinal quantitativo quase experimental, com uma amostra de 25 indivíduos, ambos os sexos, com faixa etária entre 18 e 35 anos, residentes do município de Porto Alegre-RS e da região metropolitana e que não apresentam doenças associadas. 0 método utilizado para a coleta dos dados constou de um exame postural e uma avaliação de classificação da dor através: a) da aplicação da Escala Visual Analógica (EVA); b) da observação clínica subjetiva; c) das medidas de referência da escápula. Resultados: Houve uma melhora significativa na redução da dor e no alinhamento postural escapular, tanto na altura quanto nas básculas. Conclusão: A ventosaterapia mostrou-se um método seguro, de fácil aplicabilidade e com bons resultados em relação a redução das tensões musculares, melhorando o alinhamento postural e a redução da dor nos indivíduos avaliados.

\section{PALAVRAS-CHAVE}

Ventosaterapia; Tensão muscular; Dor e alinhamento postural escapular. 


\section{INTRODUCTION}

The body posture defined as correct is that which is able to generate minimum stress and effort to the body and act at its maximum efficiency. However, an incorrect posture is one that generates an increase in muscle tension, leading to a musculoskeletal imbalance that may cause postural dysfunctions (Sedrez et al., 2015; Baroni et al., 2010). Currently, these postural changes are increasingly common, since they affect people from preschool age to advanced adulthood. In young adults it can cause a socioeconomic impact affecting their activities of daily living and sources of income (Blois et al., 2016; Goulart et al., 2016).

In the studies by Kussuki et al. (2007) and Larsen et al. (2019), although they are from different decades, both conclude that postural changes affect the human body. The changes in the shoulder girdle are increasingly common due to the habits of today's daily life. Characterized by the presence of new technologies, prolonged work on computers, repetitive tasks, and increased sedentariness in the population.

Silva (2016), point out that there is a high prevalence of postural alterations in schoolchildren. Among these alterations, there are those related to tensions of the trapezius muscles that can influence the balance of the scapular waist, asymmetry that can be visualized by the unevenness of the height of the scapulae (LARSEN et al., 2019). The trapezius muscle is one of the main actuators in the scapular girdle, in synergistic action of its upper and lower portions, it is responsible for the movement of adduction and upper rotation of the scapula during arm elevation (Sahrmann et al., 2017). With repetition or continuous activation of this musculature, it can end up overstressing itself, becoming ineffective to perform its movements in full amplitude, as well as the movements requested by the motor system (Culham and Peat, 1993).

The improper positioning of the scapula presents a high prevalence in scapular girdle dysfunctions, and may even cause possible pain due to an increase in tension in the scapular girdle region (Silva et al., 2018). The pain caused by dysfunctions and muscle tension in the scapular waist, can be evaluated through the Visual Ana$\log$ Scale (VAS). The rating ranges from 0 to 10 , being 0 no pain; 1 to 3 mild pain; 4 to 6 moderate pain; 7 to 9 severe pain and 10 unbearable pain (Silva et al., 2009).
It is of great relevance to perform a detailed postural evaluation, because from this, it is possible to draw a precise diagnosis providing subsidies in the choice of the most appropriate treatment to be applied. There are many ways to perform a postural assessment, either by palpation, radiography, photographic record, visual inspection and clinical evaluation, this being the most common and most prevalent found in studies, because it is easily accessible and has great repercussion on physical therapy practice (Santos, 2011; Lunes et al., 2009).

There are several effective methods to reduce muscle tension, including massage therapy, which has several techniques such as the application of suction cups (this technique belongs primarily to Chinese medicine, even older than massage therapy itself). Currently, suction therapy has gained space in therapeutic practice, but there is still a great lack of studies in this area to prove its effects (Lowe, 2017). Among the benefits of this technique are the negative pressure that promotes a stretching of the skin and underlying tissue, as well as a dilation of capillaries. Stimulating increased tissue blood flow. Evidence proves that the effects are local and systemic (Lowe, 2017; Wang et al., 2017).

Campos and Santos (2015), confirm these factors when they report that the use of suction cups reduces pain and is beneficial when used with prior knowledge of the method, as well as, causes patients who use it, pain reduction, muscle relaxation and increased blood flow. This is in line with the studies of Moura et al. (2018) and Wang et al. (2017), but both emphasize that there is still the need to establish standardized application protocols for a more effective implementation of this intervention.

Thus, this study aimed to evaluate and compare the acute and chronic effects of massage therapy with manual vacuum suction cup in a sliding mode on muscle relaxation in the trapezius muscle, through the evaluation of the position of the height and the bascules of the scapulae, and on pain.

\section{MATERIALS AND METHODS}

This is a quantitative longitudinal quasi-experimental clinical study. Approved by the Ethics and Research on Human Beings Committee of the Centro Universitário Metodista - IPA, in Porto Alegre/RS, Brazil (CAAE: 
16592619.1.0000.5308/approval number: 3.524.163) before recruiting volunteers. This study complies with the CNS Res. 466/12.

\section{Study design}

The sample was composed of 25 people, of both genders with ages between 18 and 35 years. All the people who were evaluated were duly informed and signed the Informed Consent Form (ICF). Patients who reported tension and/or pain in the trapezius muscle region; were not using continuous medication for pain and/or muscle relaxation; were not using any type of treatment related to cupping during the collection; were sedentary or did not exercise on the day of the collection and showed interest in participating in the study, receiving the proposed treatment were included in the study. The individuals who were excluded from the study had a diagnosis of injury to the trapezius muscle and/ or any pathologies associated with the scapular waist and patients who did not adapt to the evaluation or intervention processes.

The method used for data collection consisted of postural examination and assessment of pain classification through: a) application of the Visual Analogue Scale (VAS) according to the model adapted from Silva et al. (2009), b) subjective clinical observation, c) reference measurements of the scapula.

\section{Intervention}

The study took place during ten meetings (twice a week, with a minimum interval of 48 hours between each session) in a room with a stretcher and a quick massage chair, provided by the Integrated Clinics of IPA and/ or in places indicated by the participants (at home). The data collection was done as follows: The volunteers were selected intentionally, not randomly. Through recruitment via media and social networks, with most participants coming from the Methodist University Center-IPA and the others from the community in the northern region of Porto Alegre/RS. After signing the TCLE, the volunteer answered a questionnaire to characterize the sample (with identification data and inclusion and exclusion criteria) and the visual analog scale (VAS) (Silva et al., 2009).

Then a physical exam was performed, with the patient in orthostasis and with the trunk bare. In which, the height of the scapulae was measured from the inferior angles of the same, with a ruler positioned perpendicular to the inferior angles of the volunteer's scapulae, a line was drawn from the angles of the scapulae to the spinous processes of the spine, after which, it was verified which was higher or lower and then the measures were recorded.

The measurement of the scapulae was also performed, through the distances of the internal superior and inferior edges of the scapulae, with a ruler positioned from the internal superior edge, parallel to the medium line of the volunteer's trunk (spinous processes of the spine), a line was drawn between them, and the same was done in the internal inferior edge of the assessed person. And then, a comparative calculation was performed between the two sides, in which, when a difference greater than $0.1 \mathrm{~cm}$ was found between the upper edges (right or left) and their midline, it was classified as suggestive of a medial bascule (right, left, or both).

On the other hand, when there was a greater difference between the lower edges and the midline of the patient, it was classified as a lateral bascule.

After the evaluation, the protocol was initiated with the participant lying in ventral decubitus or sitting in the quick massage chair. The application of the protocol started on the side of the scapula with the highest elevation, according to the evaluation performed, an introductory manual massage with the application of a dermocosmetic cream, called Neutral Body Massage Cream - by D'água Natural $\AA$ to prepare the tissue for the application of the suction cup. A superficial and deep sliding was performed in the trapezium region, lasting approximately 30 seconds to 01 minute (depending on the size of the trapezium region of the assessed person), the sliding was performed from cranial to distal direction, in the direction of the muscle fibers.

Subsequently, a manual vacuum suction cup was applied, with soft and moderate pressure (depending on pain tolerance and the patient's skin reaction when related to erythema and ecchymosis), these pressures defined by markings on the application cup (suction cup) and on the application gun. The movements performed with the suction cup were sliding from cranial to distal direction, in the direction of the muscle fibers of the trapezius muscle for 10 minutes. We used a manual vacuum cup application gun $(22 \mathrm{~cm}$ - total length, cylinder that produces the vacuum, $3.5 \mathrm{~cm}$ wide and $7 \mathrm{~cm}$ high, and coupling nozzle of the cup with $15 \mathrm{~mm}$ diameter), acrylic suction cup number $01(4.5 \mathrm{~cm}$ - height and internal diameter), both from the brand "dong yang".

After the massage therapy intervention on the higher side (according to what was found in the first me- 
asurement before the initial intervention), the height and the scapular bulges were measured again, and then, the same applications were performed on the other side, of the less elevated scapula of the assessed (according to the first measurement before the initial intervention). At the end of the intervention, the participant answered the VAS again, and the height and scapular bulges were evaluated and measured again. This protocol was performed in all 10 visits. At the end of the last visit the participant answered the following questions:

How did you feel participating in this research after the application of the 10 interventions?

( ) Worse ( ) Normal ( ) Better ( ) Not noticed any difference

Would you continue/return to participate in interventions with suction cups?

Yes ( ) No ( ) Maybe ( )

\section{DATA ANALYSIS TECHNIQUES}

At the end of the analyses, the data were collected and stored in a spreadsheet (Microsoft Excel). The normality of quantitative data was assessed using the Shapiro-Wilk test, and the data presented as mean \pm standard deviation.

Comparison between quantitative data was performed using a repeated measures analysis of variance followed by a Bonferroni post-test to evaluate differences between the times: pre and post care 1 , pre and post care 5 , and pre and post care 10 , as well as the evaluation between the times pre care 1 and pre care 10 .
Qualitative data were presented as relative frequency and the proportion of data were compared using McNemar's test. A significance level of $\mathrm{p}<0.05$ was adopted for all tests. The statistical program SPSS 20.0 (SPSS Inc., USA) was used.

\section{RESULTS}

In the sample characterization table (Table 1), we find the data referring to the volunteers who participated in this research. There were no sample losses in this study, so the tables below refer to the total of those recruited for the study (25 participants).

Table 1. Characterization of the sample.

\begin{tabular}{|l|l|}
\hline Age (years) & $24,40 \pm 4,17$ \\
\hline Sex (Female) & $76 \%$ \\
\hline Exercise (didnotperform) & $72 \%$ \\
\hline Weekly exercise frequency (days/week) & $28 \%$ \\
2 & $8 \%$ \\
3 & $8 \%$ \\
5 & $8 \%$ \\
6 & $4 \%$ \\
\hline Medications (notused) & $64 \%$ \\
\hline Treatment (didnotperform) & $88 \%$ \\
\hline
\end{tabular}

Quantitative data presented as mean \pm standard deviation. Qualitative data presented in relative frequency.

The comparison of the effects pre and post treatment with the suction cup on height, scapular bulging, and pain is shown in Table 2. The data were recorded before and after every treatment.

Table 2. Comparison of the effects pre and post treatment with suction cup on height, scapular bulging and pain.

\begin{tabular}{|c|c|c|c|c|c|c|}
\hline & & A1 & & A5 & & 10 \\
\hline & Pre & Post & Pre & Post & Pre & Post \\
\hline $\begin{array}{l}\text { Scapula height }(\mathrm{cm}) \\
\text { Right side }\end{array}$ & $0,18 \pm 0,06$ & $0,12 \pm 0,06$ & $0,16 \pm 0,05$ & $0,00 \pm 0,08^{*}$ & $0,10 \pm 0,04^{* *}$ & $0,05 \pm 0,02$ \\
\hline Leftside & $0,33 \pm 0,11$ & $0,10 \pm 0,04^{*}$ & $0,16 \pm 0,05$ & $0,08 \pm 0,04$ & $0,17 \pm 0,06^{* *}$ & $0,02 \pm 0,02^{*}$ \\
\hline $\begin{array}{l}\text { Weighing scale }(\mathrm{cm}) \\
\text { Right side }\end{array}$ & $4,08 \pm 0,52$ & $3,60 \pm 0,55$ & $3,64 \pm 0,56$ & $3,80 \pm 0,53$ & $3,44 \pm 0,57$ & $2,90 \pm 0,58$ \\
\hline Leftside & $4,04 \pm 0,52$ & $3,32 \pm 0,55$ & $3,64 \pm 0,56$ & $2,96 \pm 0,58$ & $4,12 \pm 0,53$ & $2,48 \pm 0,57^{*}$ \\
\hline Pain & $3,26 \pm 0,45$ & $0,94 \pm 0,25^{*}$ & $1,72 \pm 0,33$ & $0,54 \pm 0,10^{*}$ & $0,98 \pm 0,19^{* *}$ & $0,32 \pm 0,07^{*}$ \\
\hline
\end{tabular}

Data presented as mean \pm standard deviation. Comparison between time points using a repeated measures analysis of variance variance analysis of repeated measures followed by Bonferroni post-test.

*Indicates significant difference compared to the pre-care time point $(\mathrm{p}<0.05)$.

$* *$ Indicates significant difference compared to the pre-care 1 time point $(\mathrm{p}<0.05)$.

A1, A5 and A10, indicate data referring to the 1st, 5th and 10th attendance respectively. 
The bascules were evaluated always before and after all the attendances, we find their comparisons pre and post attendances with suction cup in Table 3.

Table 3. Comparison of the pre and post effects of the suction cup on the bascules.

\begin{tabular}{|c|c|c|c|c|c|c|}
\hline \multirow[t]{2}{*}{ Scales } & \multicolumn{2}{|c|}{ A1 } & \multicolumn{2}{|c|}{ A5 } & \multicolumn{2}{|c|}{ A10 } \\
\hline & Pre & Post & Pre & Post $^{\mathrm{a}}$ & Pre $^{b}$ & Post $^{a}$ \\
\hline \multicolumn{7}{|c|}{ Right (\%) } \\
\hline Neutral & 28 & 36 & 36 & 32 & 40 & 48 \\
\hline Medial & 24 & 24 & 20 & 28 & 16 & 16 \\
\hline \multirow[t]{3}{*}{ Lateral } & 48 & 40 & 44 & 40 & 44 & 36 \\
\hline & Pre & Post ${ }^{\mathrm{a}}$ & Pre & Post $^{\mathrm{a}}$ & Pre $^{\mathrm{b}}$ & Post ${ }^{a}$ \\
\hline & \multicolumn{6}{|c|}{ Left (\%) } \\
\hline Neutral & 28 & 40 & 36 & 48 & 28 & 56 \\
\hline Medial & 28 & 28 & 20 & 16 & 20 & 16 \\
\hline Lateral & 44 & 32 & 44 & 36 & 52 & 28 \\
\hline
\end{tabular}

Data presented as relative frequency (\%). The proportions of data between the moments were compared using the McNemar test. *Indicates difference in proportions between pre- and post-care $(\mathrm{p}<0.05)$.

*Indicates difference in proportions between pre A1 and pre $\mathrm{A} 10(\mathrm{p}<0.05)$.

$\mathrm{A} 1, \mathrm{~A} 5$ and A10, indicate data referring to the $1 \mathrm{st}, 5$ th and 10 th attendance respectively.

At the end of the $10^{\circ}$ service, all volunteers were asked two satisfaction questions regarding their participation in this study, and the results are shown in Table 4.

Table 4. Questions of satisfaction in relation to the services provided with the cupping therapy.

How did you feel participating in this research

after the application of the 10 interventions?

Better Would you continue/return to 100\%

participate in interventions with cupping

therapy?

Yes $\quad 96 \%$

Maybe $4 \%$

Data presented in relative frequency.

\section{DISCUSSION}

In our research with the application of suction therapy, we found significant improvement in the alignment of the scapulae, in relation to their heights, as well as their bascules and pain reduction in the scapular waist region.

Based on the findings of the studies by Saha et al. (2017) and Chi et al. (2016), one can see how beneficial suction cup is in relation to pain reduction. Our study confirms this, since there was a significantly positive difference in pain reduction, when we compared the mean of pain in the first pre-service (3.26), with the last post-service $(0.07)$ of our volunteers. This corroborates the review study of Campos and Santos (2015), where they emphasize the importance of cupping therapy in reducing pain and increasing muscle relaxation, in relation to trigger points caused by increased tension in different muscles of the body, since pain influences the behavior of the rest of the body muscles, as well as their postural positioning, due to muscle pain caused by these accumulations of tension (Nunes et al., 2013; Suyanni et al., 2014).

Nunes et al. (2013) and Goulart et al. (2016), despite being studies that address different techniques than the one we used in our research, we realize how important it is to address postural alignment, especially scapular alignment. Since this is something relevant at all ages, and can also be corrected with different techniques, as long as they are well applied.

The study of Moura et al. (2018), is a systematic review and meta-analysis study, where several studies we- 
re found on techniques that address the application of the suction cup, however, no studies were addressed that were similar to this one in question, especially in relation to the application of the suction cup with sliding application. Most of the studies described were with the application of local pressure, "fixed suction cup", so the volunteers were always left with marks in the places where it was applied. In our study we were able to have a differential in relation to this factor, due to the fact that we had performed the method of sliding suction cup and with standard control of pressure applied in each patient, our volunteers did not present large hematomas, commonly known after application of the suction therapy method, with the exception of only 02 isolated cases at the beginning of the treatment, where they received the necessary care and were able to remain in the study, not presenting any further hematoma during the entire study period.

In all the studies, we can see that muscular tension is the greatest cause of postural alterations and consequently the greatest cause of muscular pain. Thus, one can see the importance of interventions of quick effectiveness, easy applicability and little invasive, so that there can be a better adherence and response to treatment. Saha et al. (2017) and Silva et al. (2019), both report on the secondary factors of pain generated by muscle tension, as well as the retraction caused by it, which can be a limiting factor for several other factors, since it ends up influencing the quality of life (QL), as well as the performance of our activities of daily living (ADL). The studies of Coelho and Sousa (2019), corroborate these statements, when they state the importance of ventosatherapy in reducing stress, which is increasingly affecting the population in general and, consequently, harming various aspects of their daily lives.

Although our study has not approached QL as most of the other studies we found, which will serve us as a future possibility to improve our study in the future, even so, we can assume that our study has collaborated with the improvement of QL in our volunteers. Once according to the results found in our study in comparison with others that approached this aspect, if we had also evaluated it, there would be a high probability that we would have positive results regarding the improvement of QL as well.
Most of the studies found, had positive results after the suction cup protocol, which we believe must have been influenced by the reduction of tension and muscle pain caused by them. This is in line with our results, regarding the improvement of postural alignment found in the scapulae, as well as the reduction of pain, since by improving muscle tension there was a better postural alignment and, consequently, the reduction of muscle pain in our volunteers.

We asked two questions about satisfaction of participation in this research at the end of the research, which was not found in the other studies. We obtained satisfactory results, where $100 \%$ of the volunteers reported feeling better after the treatment, and $96 \%$ also stated that they would participate in further research with suction cups.

To date, there are no studies that address the scapular bascules; however, we know their importance in relation to postural scapular alterations. Therefore, our study with the suction cup method contributes to their correction, when we compare our own results in relation to the first pre-care, where the right and left bascules were only $28 \%$ in both, in neutral position, i.e., in the correct position, and in the last post-care, we found $48 \%$ neutral bascules to the right and $56 \%$ to the left. This is of great relevance for a better scapular and consequently postural alignment, and this is also a great factor for the proof that suction therapy relaxes the musculature, helping in the postural correction and consequently significantly reducing muscular pain caused by tensions.

\section{CONCLUSION}

With this study we can conclude that cupping therapy was able to promote the alignment of the scapulae in relation to their heights and bascules (reducing tension and generating muscle relaxation), as well as the reduction of pain in the trapezius muscle region.

\section{FUTURE CONSIDERATIONS}

The technique of manual vacuum therapy in a sliding mode is of great relevance, because in addition to the results concluded in this study, it was also perceived that it promotes physical well-being and a better perfor- 
mance of daily activities in individuals undergoing this treatment. Thus, it is of great relevance for future research, as well as for the use of this method in patients with pain, trapezius muscle tension, and scapular postural alterations.

This study contributes to the dissemination of this technique, as well as pointing out that for a better realization of this method, it must be used by trained pro- fessionals in the area, with training in the same. However, despite the technique having already been proven in different studies, besides this one, because it is an ancient method, it still needs more studies in the area and more scientific proof. Since the greatest difficulty in carrying out this study was precisely to find good studies with scientific proof that could be used to conduct our research. 


\section{REFERENCES}

Baroni B. M. et al. Prevalência de alterações posturais em pacientes de musculação. Fisiot. Mov, Curitiba, v.23, n.1, p.129139, jan./mar. 2010. Available in:<https://www.scielo.br/j/ $\mathrm{fm} / \mathrm{a} / \mathrm{XTLMy} 5 \mathrm{dGzvdHrTjYcxP} 4 \mathrm{vgc} /$ ?format=pdf\&lang=pt $>$. Access in: 26 mar. 2019.

Blois R. et al. Efeitos do método pilates no tratamento das alterações posturais em universitários. Inspirar, ed. 38, v.9, n.2, p. 31-36, apr./may./jun. 2016. Available in:<https://www.inspirar.com.br/wp-content/uploads/2016/08/artigo5-ed38-abrmai-jun2016.pdf>. Access in: 26 mar. 2019.

Campos G.H.; Santos. C.T. Treatment of trigger points with cupping therapy. Revisa, Goiânia, v.2, n.4, p.146-54, jul./dez. 2015. Available in:<http://revistafacesa.senaaires.com.br/index. php/revisa/article/view/248/105>. Access in: 28 mar. 2019.

Chi L. M. et al. The Effectiveness of Cupping Therapy on Relieving Chronic Neck and Shoulder Pain: A Randomized Controlled Trial. Evidence-Based Complementary andAlternative Medicine, Taiwan, ed.2016, n.7, p.1-7, mar. 2016. Available in: <https: / /www.ncbi.nlm.nih.gov/pmc/articles / PMC4814666/pdf/ECAM2016-7358918.pdf>. Access in: 15 mar. 2020

Coelho, N. L.; Sousa, J. T.; Watanabe, L. A. R. A utilização da medicina tradicional chinesa na redução do estresse. ScireSalutis, Sergipe, v.9, n.1, p.20-29, oct. 2018 a jan. 2019. Available in: <http://www.sustenere.co/index.php/sciresalutis/article/view/CBPC22369600.2019.001.0003/1495>. Access in: 02 nov. 2019

Culham, E.; Peat, M. Functional anatomy of the shoulder complex. Journ. Of Orthop. Sports Phys. Ther, Alexandria, v.18, n.1, p. 342-350, jul. 1993. Available in:

<https: / / ww w.jospt.org/doi /pdf/10.2519/ jospt.1993.18.1.342>. Access in: 20 mar. 2019.

Goulart I.P. et al. Postural analysis of the cervical spine and shoulder girdle practitioners. Unipampa, Uruguaiana, v.23, n.1, p.1009-2950, jan./mar. 2016. Available in: <https://www.scielo.br/j/fp/a/NXdCyX4bypdDCYphhsm8yb x/?format=pdf\&lang=en>. Access in: 21 mar. 2019.

Kussuki M. O. M.; João S. M. A.; Cunha A. C. P. Postural characterization of obese children spine between 7 and 10 years old Fisioterapia em Movimento, Curitiba, v. 20, n.1, p.77-84, jan./ mar. 2007. Available in: <https://periodicos.pucpr.br/index. $\mathrm{php} /$ fisio/article/view/18843/18227>. Access in: 17 apr. 2019.

Larsen, C. M. et al. Clinical assessment methods for scapular positioning and function. An inter-rater reliability study. Physiotherapy Theory and Practice, London, v.1, n.19, p.13991420, mar. 2019. Available in: <https://www.tandfonline.com/doi/full/10.1080/09593985
.2019.1579284?scroll=top\&needAc cess=true $>$. Access in: 22 sep. 2019

Lowe, D. T. Cupping therapy: An analysis of the effects of suction on skin and the possible influence on human health. Complementary Therapies in Clinical Practice, Tacoma, v. 29, n.1, p.162-168, nov. 2017. Available in:

<https://www.sciencedirect.com/science/article/abs/pii/ S1744388117304024?via\%3Dihub\#!>. Access in: 10 oct. 2019.

Lunes D.H. et al. Análise comparativa entre avaliação postural visual e por fotogrametria computadorizada. RevBras de Fisiot, São Carlos, v.13, n.4, p.308, jul./agu. 2009. Available in: <https://www.scielo.br/j/rbfis/a/K3J45vByb6HgPyKP7C6vLVL/?format=pdf\&lang=pt $>$. Access in: 10 may. 2019.

Moura C.C. et al. Cupping therapy and chronic back pain: systematic review and metaanalysis. Rev. Latino-Am. Enfermagem, Ribeirão Preto, v.26, e.3094, p.01-15, 2018.

Available in:

<https://www.scielo.br/j/rlae/a/wHqRXxHjCC96prj9WCKQ shN/?format=pdf\&lang=en>. Access in: 03 jun. 2019.

Nunes S.M.J. et al. Análise por fotogrametria da influência da bandagem funcional no alinhamento da cintura escapular em idosos. ConScientiae Saúde, São Paulo, v.12, n.2, p. 259-265, apr./jun. 2013. Available in: <https://www.redalyc. org/pdf/929/92928018011.pdf>. Access in: 11 agu. 2019.

Saha F.J. et al. The Effects of Cupping Massage in Patients with Chronic Neck Pain - A

Randomised Controlled Trial. Complement Med Res, Germany, v.24, n.1, p.26-32, feb. 2017. Available in: <https://www.karger.com/Article/Pdf/454872>. Access in: 13 agu. 2019.

Sahrmann, S. et al. Diagnosis and treatment of movement system impairment syndromes. Brazilian Journal of Physical Therapy, St. Louis, v.21, n. 6, p.391-399, agu./sep. 2017. Available in: <https://www.ncbi.nlm.nih.gov/pmc/articles/ PMC5693453/pdf/main.pdf>. Access in: 25 mar. 2019.

Santos, A. Diagnóstico Clínico Postural - Um Guia Prático. 5. ed. São Paulo: Summus, 2011.

Sedrez J.A. et al. Fatores de risco associados a alterações posturais estruturais da coluna vertebral em crianças e adolescentes. Rev Paul Pediatri. São Paulo, v.33, n.1, p.77-81, mar. 2015. Available in: <https://reader.elsevier.com/reader/sd/ pii/S0103058214000380?token=94559D020D61EE7D B53AF68732A707FC6E54D75D4822A4FDD5A5442229334892CD57130B4F5F8A4577D6 8DE0C34FC6BE\&originRegion=us-east-1\&originCreati on=20210830192556 >. Access in: 25 mar. 2019.

Silva H.J.D.A. et al. Dry cupping in the treatment of individuals with non-specific chronic low back pain: a protocol for a placebo-controlled, randomised, double-blind study. BMJ Open, 
Santa Cruz (Rio Grande do Norte), v.9, e.032416, p.01-09, dez. 2019. Available in:

<https://bmjopen.bmj.com/content/bmjopen/9/12/ e032416.full.pdf>. Access in: 05 may. 2020.

Silva, P. C. Alterações posturais em crianças frequentadoras de escolas municipais da cidade de Salvador-Bahia. Diálogos \& Ciência, ano 16, n. 37, p.16-30, agu. 2016. Available in: <https://docplayer.com.br/26201969-Alteracoes-posturais-em-criancas-frequentadoras-deescolas-municipais-da-cidade-de-salvador-bahia.html>. Access in: 10 nov. 2019.

Silva C.F.et. al. Análise das escalas de dor: Revisão de literatura. Revista Brasileira de Ciências da Saúde, São Caetano do Sul. v.7, n.19, p.01-04, jan./mar. 2009. Available in:

$<$ https://seer.uscs.edu.br/index.php/revista_ciencias_saude/ article/view/337/159>. Access in: 28 mar. 2019.

Silva R.M. et al. Evolução histórica do conceito de estresse. Rev.
Cient. Sena Aires, Goiânia, v.7, n.2, p.148-56, jul./sep. 2018. Available in:

<http://revistafacesa.senaaires.com.br/index.php/revisa/article/viewFile/316/225>. Access in: 18 apr. 2019.

Suyanni M.C.P.; Gouveia P.M.G. Efeito da inibição muscular na funcionalidade do trapézio fibras superiores. Fisioterapia Brasil, Parnaíba, v.15, n.3, p.189-194, mai./jun. de 2014. Available in:

$<$ https://portalatlanticaeditora.com.br/index.php/fisioterapiabrasil/article/view/338/589>. Access in: 30 oct. 2019.

Wang, Y.T., et. al. The effect of cupping therapy for low back pain: A meta-analysis based on existing randomized controlled trials. Journal of Back and Musculoskeletal Rehabilitation, Guangzhou, v.30, n.6, p.1187-1195, jan. 2017. Available in: <https://content.iospress.com/articles/journal-of-back-and-musculoskeletalrehabilitation/bmr169736> Access in: 09 may. 2019. 